\title{
REPRODUCTIVE PLASTICITY IN YELLOWJACKET WASPS: A POLYGYNOUS, PERENNIAL COLONY OF VESPULA MACULIFRONS
}

\author{
By Kenneth G. Ross* and P. Kirk Visscher \\ Department of Entomology \\ Cornell University \\ Ithaca, NY 14853
}

\section{INTRODUCTION}

Social wasps in the family Vespidae are thought to have originated in the southeast Asian tropics (Richards, 1971; Spradbery, 1973a; but see Carpenter, 1982). Members of the subfamily Vespinae presumably evolved monogyny and an annual colony cycle as adaptations to cold winters in north temperate regions. Exceptions to this characteristic social organization and colony ontogeny in vespines have become increasingly apparent (Ross \& Matthews, 1982). In climatically favorable areas of their natural range (Tissot \& Robinson, 1954; Duncan, 1939; Vuillaume et al., 1969; Akre et al., 1980), and in areas newly colonized (Spradbery, 1973b; Perrott, 1975; Thomas, 1960) several species of Vespula (subgenus Paravespula) facultatively form polygynous, perennial colonies. This capacity demonstrates great plasticity in the behavioral ecology of Paravespula species, and is intriguing in light of its implications for theories concerning the evolution of eusociality in the Vespidae.

We here report the discovery of a polygynous, perennial nest of Vespula maculifrons (Buysson) from the southeastern U.S. With this discovery, all non-parasitic Nearctic representatives of the subgenus Paravespula have been shown to exhibit this atypical colony ontogeny.

*Present address: Department of Entomology, University of Georgia, Athens, GA 30602.

Manuscript received by' the editor February' 25, 1983. 


\section{Methods}

Nest site and excavation

A large Vespula maculifrons colony was discovered on 25 November 1981, nesting in sandy soil in sand pine scrub habitat at the Archbold Biological Station in Highlands County, Florida (27 $11^{\prime}$ $\mathrm{N}, 81^{\circ} 21^{\prime} \mathrm{W}$ ). Flight from the colony was observed on 1 February 1982 and 11 March 1982 and we excavated the colony on 20 March 1982.

We placed traps (similar to Fig. 193 in Edwards, 1980) on each of the two entrances of the nest in the early morning and aroused the nest by pounding the ground. Workers (and some males) flying from the nest were caught in the traps. We discharged a carbon dioxide fire extinguisher into one of the entrances, which chilled and partially narcotized wasps remaining inside; we then excavated the nest.

Because of inadequate narcosis of the wasps and because the nest was intersected by several large roots, we were unable to remove the nest intact. Many combs were broken into several pieces. The pieces were placed in large polyethylene bags and kept frozen until examined.

\section{Analysis of nest contents}

We traced each comb fragment onto a sheet of paper of uniform weight, and recorded a visual estimate of the proportions of cells containing capped brood, eggs, and uncapped brood. Of those cells which contained eggs, we estimated the proportion which contained more than one egg. Any large (queen-size) cells present were counted individually in each of the above categories.

To determine the comb area of each fragment we cut out and weighed each tracing (weight $\times \mathrm{cm}^{2} / \mathrm{g}$ for the paper $=$ area). We counted the number of small (worker-size) cells on 12 representative comb fragments totaling 3964 cells. We used the mean number of cells $/ \mathrm{cm}^{2}$ to estimate the number of cells in each of the above cell content categories for each fragment. These per-fragment estimates were then summed for the entire nest (205 comb fragments).

Sex ratio of colony'

We estimated the sex ratio of the capped brood in small cells by removing 33 pupae or pharate adults from each of $16 \mathrm{comb}$ frag- 


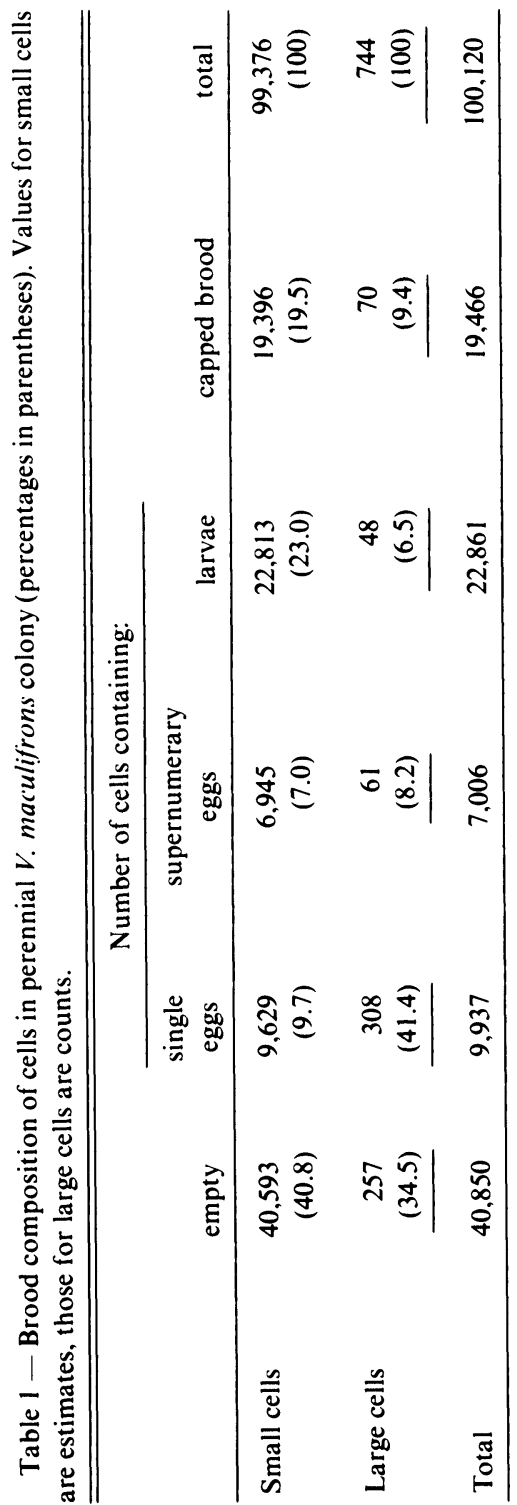


ments and determining their sex $(n=528)$. We counted and sexed all pupae and pharate adults in large cells.

To estimate the sex ratio of the adult population of the nest we weighed the two sub-populations of workers and males retrieved from the nest interior and the entrance traps. We then weighed, counted, and sexed 4 and 5 samples, respectively, of these populations. The mean number of wasps/g and the mean sex ratios of these samples were extrapolated to the population and sex ratio of the colony adults as a whole.

\section{Reproductive status of queens and w'orkers}

We dissected all queens in the nest and classified their reproductive status as follows: "Developed" ovaries had oocytes greater than $2 \mathrm{~mm}$ in length, "undeveloped" ovaries had oocytes less than $1 \mathrm{~mm}$ in length. "Inseminated" queens had spermatozoa visible microscopically in a squash mount of their spermathecae, while "not inseminated" queens had none.

To estimate the reproductive status of workers in the colony, we dissected a random sample of 100 workers and examined their ovaries. We classified them as "undeveloped" [ovarian index less than 1 (Cumber, 1949), oocytes not developed], "moderately developed" (ovarian index 1-2, maximum oocyte length $0.9 \mathrm{~mm}$ ), or "well developed" (ovarian index 3-12, oocyte length greater than $1.0 \mathrm{~mm}$ ).

\section{RESULTS}

\section{Nest structure and brood composition}

Estimated cell number and brood composition of the nest are given in Table 1 (see also Fig. 1). From comb measurements the volume of the nest cavity was estimated to be ca. 80 liters. The nest structure was roughly ellipsoid, $71 \mathrm{~cm}$ by $45 \mathrm{~cm}$. Two nest entrances were in use at the time of discovery; flight activity from each was 95 \pm 14 and $15 \pm 6 \mathrm{wasps} / \mathrm{min}$ returning at midday on 11 March (here and throughout this paper numbers in this form denote mean \pm 1 $\mathrm{SD}$, except as noted). The combs were present in at least 15 layers. Total comb area was $15,652 \mathrm{~cm}^{2}$; the combs contained an estimated 100,120 cells.

Small (worker-size) cells comprised $99.3 \%$ of all cells in the nest $(4.0 \pm 0.20 \mathrm{~mm}$ in diameter between parallel sides, range $3.7-4.7$ $\mathrm{mm}, \mathrm{n}=44$ ). Of the small cells, $16.7 \%$ contained eggs; $41.9 \%$ of 

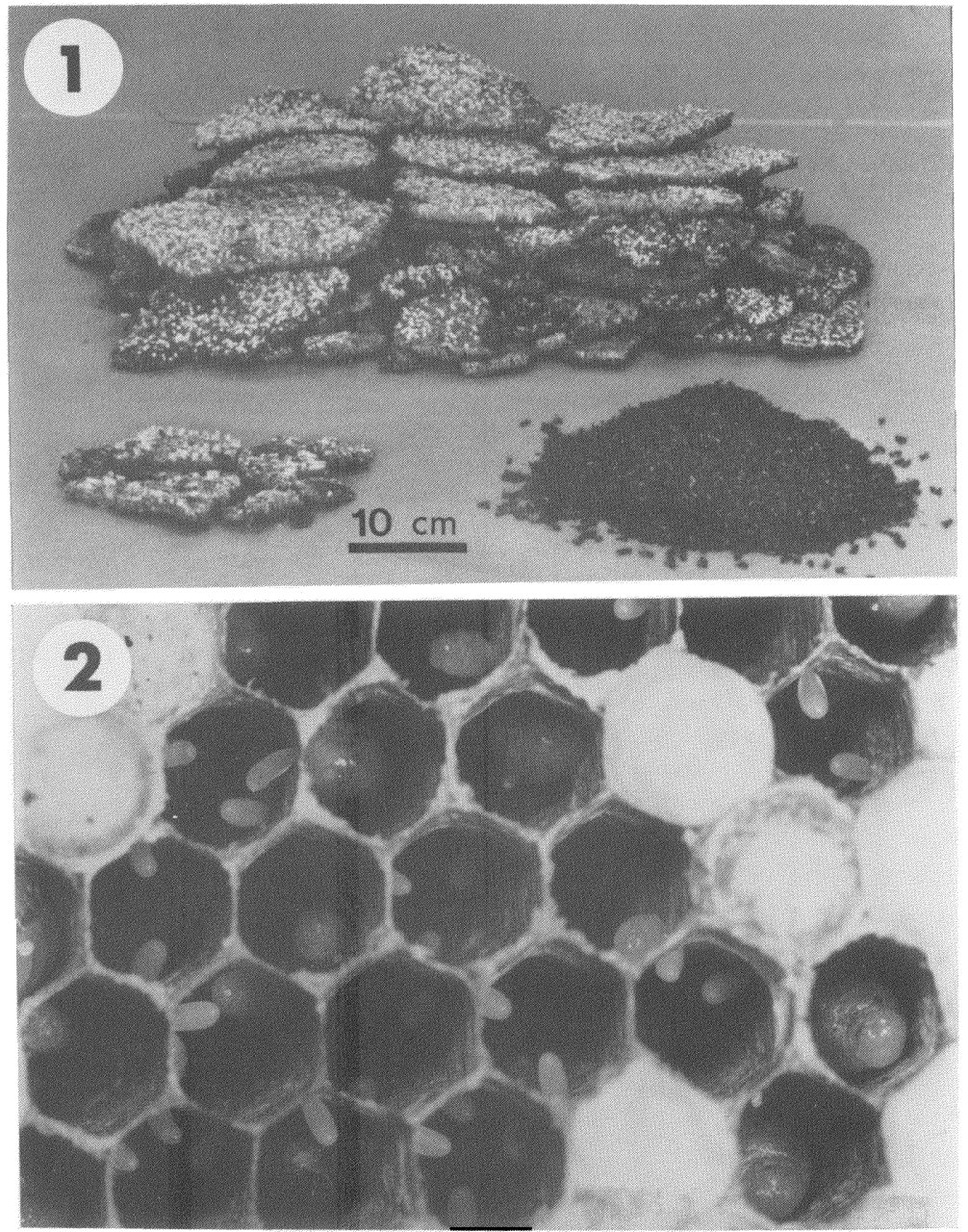

Figure 1. Comb fragments and adult inhabitants of perennial $V$. maculifions colony. Combs positioned in left foreground contain large cells.

Figure 2. Supernumerary eggs and immatures in small cells of perennial $V$. maculifrons colony. Note positions of eggs high on the cell walls. 
these contained supernumerary eggs (Fig. 2). In a sample of 119 small cells containing eggs, up to 5 eggs/cell were present $(1.9 \pm 0.89$ eggs/cell). Most of these eggs were positioned high on the cell walls. Forty-one percent of the small cells contained no brood or eggs. Most of these empty cells had reduced cell walls or were papered over indicating disuse at the time of collection (Duncan, 1939).

The sex ratio of pupae and pharate adults in capped small cells is presented in Table 2. Note that more than half of the capped brood sampled were males.

We counted 744 large cells $(5.8 \pm 0.20 \mathrm{~mm}$ in diameter between parallel sides, range $5.4-6.1 \mathrm{~mm}, \mathrm{n}=22$ ) in the nest (Table 1); these were located on 8 comb fragments, 2 of which contained exclusively large cells. Over one-third (34.5\%) of the large cells were empty; some had been papered over and the cell walls reduced. Of the $49.6 \%$ of large cells with eggs, $16.5 \%$ contained supernumerary eggs. One small comb of 29 cells appeared newly constructed. The paper was light and fragile, no meconia were present, cells on the perimeter were shallow, and each cell contained a single egg.

The capped large cells contained predominantly queen pupae and pharate adults (Table 2), but a large percentage (30.4\%) were males.

\section{Adult inhabitants}

An estimated total of $11,817 \pm 210$ (95\% confidence interval) adult wasps were collected (Table 2). Of these adults, $25.8 \pm 2.9 \%$ $(95 \% \mathrm{Cl})$ were males. Of the remaining female adults, only 23 were queens. An undetermined number of flying workers and males were not captured as the nest was collected.

We dissected all 23 queens found within the colony. Fifteen of these queens had undeveloped ovaries; only one of these was inseminated. Six queens were inseminated and possessed well developed ovaries. Two queens were classified as senescent. One of these had well developed ovaries but had no spermatozoa in her spermatheca; the oviducts appeared degenerated, pigmented, and clogged. Very little fat body was present. The other queen, found in the bottom third of the nest cavity, had apparently been dead for some time. Some abdominal sclerites had been punctured and the viscera were desiccated. One wing was missing while the other was very frayed. Both senescent queens and the six inseminated queens with developed ovaries had frayed wings and abdominal cuticular markings characteristic of physogastric, aged queens (Spradbery, 1973a). 
Table 2 - Number of capped brood and captured adults of each caste in perennial $V$. maculifrons colony (percentages in parentheses). Values for adults and capped brood in small cells are estimates, those for capped brood in large cells are counts.

\begin{tabular}{lcccc}
\hline \hline & Queens & Males & Workers & Total \\
\hline $\begin{array}{l}\text { Capped brood } \\
\text { large cells }\end{array}$ & $49(69.6)$ & $21(30.4)$ & -- & $70(100)$ \\
small cells & -- & $10,454(53.9)$ & $8,941(46.1)$ & $19.395(100)$ \\
Adults & $23(0.2)$ & $3,044(25.8)$ & $8,749(74.0)$ & $11,816(100)$ \\
\hline
\end{tabular}

We dissected 100 workers chosen at random. While $74 \%$ of the workers exhibited no ovarian development, $12 \%$ had moderately developed ovaries, and $14 \%$ had well developed ovaries.

\section{Discussion}

Although this is the first record of such a nest for $V$. maculifrons, the nest size and number of inhabitants are typical for polygynous, perennial colonies of other Paravespula species (Ross \& Matthews, 1982; Spradbery, 1973a; Edwards, 1980). In contrast, annual colonies of $V$. maculifrons from northern Georgia and western North Carolina average 6,104 small cells and 2,551 large cells at their greatest development (MacDonald \& Matthews, 1981). The perennial $V$. maculifrons colony, while containing fewer large cells, had more than 16 times as many small cells as average conspecific annual nests. Perennial nests of $V$. germanica (F.) from Tasmania and New Zealand are reported to contain up to 180 combs and four million cells (Thomas, 1960; Spradbery, 1973b). The study colony also contained almost twice as many adult workers as the most populous conspecific annual colony studied by MacDonald \& Matthews (1981).

The prodigious size of perennial, polygynous Vespula colonies does not result simply from the cumulative effects of two seasons of growth. The pre-existing nest structure and worker force presumably support a rate of production by each of the colony's queens early in the season attained only much later by annual colonies. In addition, newly recruited queens in such a colony avoid the inherent risks of haplometrotic colony founding, such as predation while foraging and early colony failure (Archer, 1980). 
Several to 50 queens are typically present in perennial Vespula colonies, although Spradbery (1973b) found up to 1000 in perennial nests of $V$. germanica in Tasmania. On the other hand, Thomas (1960) reported only a single queen in each of the perennial $V$. germanica nests he studied from New Zealand. Six of the 23 queens we found in the study colony were inseminated and possessed well developed ovaries; these were probably functional queens. The large number of worker brood we found corroborates the evidence for several egg laying queens. An additional two queens were probably former reproductives. The remaining queens could have emerged recently, as queens at all stages of development were present in the colony. Newly emerged queens in perennial colonies may mate in the nest with sibs (Ross, 1983; R. E. Wagner, personal communication) or embark on mating flights and return to the parental nest as newly recruited reproductives (Spradbery, 1973a, b). Thus, functional queens in polygynous Vespula colonies are typically regarded as being daughters of the original foundress (Spradbery, 1973b; Edwards, 1980; but see Ross \& Matthews, 1982).

The study colony contained fewer large cells than do average annual $V$. maculifrons colonies, indicating that fewer than normal queens had been reared during the first developmental season. The presence of large numbers of male and queen brood and adults indicates that the colony had been rearing reproductives throughout the winter [as is typical for other perennial Vespula (Edwards, 1980)], and a newly initiated queen comb with eggs suggests that queens would have continued to have been reared into the spring. Presumably the number of queens produced over two seasons would far exceed the productivity of an annual colony.

Over one-half of the capped brood sampled in small cells were males. The occurrence of so many male brood in the spring, the great number of supernumerary eggs, and the positions of eggs high on the cell walls suggest the likelihood of laying workers (R. W. Matthews, personal communication; Akre et al., 1982). Dissections confirmed that at least $14 \%$ of the workers possessed well developed ovaries and were probably ovipositing.

Greater than $30 \%$ of the brood being reared in large cells at the time of colony collection were males. This represents a considerably larger figure than has been previously reported for annual Paravespula colonies, in which large cells contain almost exclusively 
queen brood (MacDonald \& Matthews, 1981; Spradbery, 1971; MacDonald et al., 1974). Perhaps pressure to find empty cells resulted in workers ovipositing in large cells.

The presence of many laying workers in large, diffuse nest structures is not unexpected if queens exert reproductive control via the dissemination of volatile or trophic pheromones (Ikan et al., 1969; Landolt et al., 1977). The percentages of laying workers and supernumerary eggs we found were in close agreement to those reported for a queenless nest of Vespa simillima Smith (Yamane, 1974). Laying workers in annual vespine colonies may be common during the phase of colony decline, also suggesting diminished queen control (R. W. Matthews, personal communication; Montagner, 1966; Akre et al., 1982). These workers appear to occupy regions of the nest not frequented by the queen (Edwards, 1980).

Vespine workers may indeed represent "hopeful reproductives" (West Eberhard, 1978; Lin \& Michener, 1972): while many workers never lay eggs, a significant proportion of them do and all can be regarded as having some probability of directly contributing genes to subsequent generations. This factor has not been adequately considered by theories attempting to explain the origin of eusociality by reference to a polarized view of reproductive castes (Hamilton, 1964a, b; Alexander, 1974; Spradbery, 1973a).

Our discovery of an overwintered, polygynous colony of $V . m a c u-$ lifrons completes the series of free-living North American species in the subgenus Paravespula with this life history. No members of the subgenus Vespula or the aerial-nesting genus Dolichovespula have been reported to exhibit this atypical colony cycle (Akre \& Reed, 1981). Perennial, polygynous colonies have been reported for $V$. squamosa (Tissot \& Robinson, 1954; Ross \& Matthews, 1982), whose affinities with other Vespula species are unclear (Akre et al., 1980; see also Archer, 1981).

The ability to retain colony social cohesion through two developmental seasons and to tolerate the existence of multiple functional queens points to great ecological and behavioral plasticity in the subgenus Paravespula. Members of this group differ from other temperate vespines in additional biological attributes including: (1) delay of reproductive production until fall or early winter and consequent increased duration of colony life span, (2) development of populous colonies and large nests, (3) ability to successfully colonize 
new areas of the world when introduced by man, and (4) tendency for workers to become scavengers on carrion or human food and refuse in the late summer. The common possession of these derived features supports a monophyletic origin of this group within the Vespinae. The interaction of these same features accounts for the greater public health importance of these species relative to other vespines.

The vespid subfamilies Polistinae and Vespinae, comprised exclusively of eusocial species, are thought to have evolved from a common social ancestor (Carpenter, 1982). The Polistinae are diverse in their methods of colony founding and number of functional reproductives (Iwata, 1976; Jeanne, 1980); their social behavior appears loosely associated with a tropical or temperate existence. In contrast, all vespines are characteristically haplometrotic and monogynous, and form annual colonies (thought to be temperate adaptations), regardless of their distribution (Iwata, 1976; van der Vecht, 1957; Akre et al., 1980). Thus, the characteristic social organization of the Vespinae appears to be the expression of a common ancestral trait, rather than an immediate response to ecological conditions. This interpretation suggests that the Vespinae may have originated in temperate regions rather than in the tropics (Carpenter, 1982), as has been previously assumed.

The evolution of eusociality in vespids is thought to have occurred by one of two/general routes: (1) the subsocial or matrifilial monogynous route in which prolonged maternal care provides opportunities for social interaction between a foundress and her offspring (Evans \& West Eberhard, 1970; Spradbery, 1973a), or (2) the polygynous or parasocial route in which nesting associations of foundresses of the same generation lead to increasingly complex levels of social organization (Lin \& Michener, 1972; West Eberhard, 1978). Insofar as the occurrence of occasional polygyny in the Vespinae bears on the social origins of this group, the recurrent ability of colonies to tolerate multiple functional reproductives strengthens an argument for the evolution of eusociality via the parasocial route in the Polistinae + Vespinae. The occurrence of perennial, polygynous colonies of Vespula may be viewed as a reversion to a more primitive behavioral and physiological mode. Further investigations of this phenomenon should aid in elucidating the environmental and social contexts under which it occurs. 


\section{SUMMARY}

We describe a polygynous, overwintering colony of Vespula maculifrons from central Florida. The nest contained about 100,000 cells; many brood of all castes, at all developmental stages; over 8000 adult workers and 3000 adult males; and 23 adult queens, at least six of which were functional egg-layers. Supernumerary eggs were found in 7000 of the small cells, often placed high on the cell walls. Of 100 workers dissected, 14 exhibited substantially developed ovaries and had probably been laying eggs.

With this report, all non-parasitic neartic species of the subgenus Paravespula are known to occasionally exhibit this unusual life history, in contrast to the uniformly monogynous, annual species in the subgenus Vespula. Paravespula also exhibit more plasticity in their nesting and foraging habits. We discuss the ability of perennial colonies to tolerate multiple queens and relate this ability to the question of the evolution of eusociality in the Polistinae+Vespinae.

\section{ACKNOWLEDGEMENTS}

We thank Chester Winegarner for discovering the colony, monitoring its survival, and helping in excavation. James M. Carpenter and George C. Eickwort reviewed the manuscript and made helpful suggestions. We thank James Layne and Archbold Expeditions for use of the facilities of the Archbold Biological Station, and for a grant-in-aid to the junior author. Additional funding through NIH grant 5 RO1 Al16011-03, Vespid Venom Collection, awarded to Dr. Roger A. Morse.

\section{REFERENCES}

Alexander, R. (1974) The evolution of social behavior. Annual Review of Ecology and Systematics 5,325-81.

AKRE, R. D. \& REED, H. C. (1981) A polygynous colony of Vespula pensylvanica (Saussure) (Hymenoptera: Vespidae). Entomological News 92,27-31.

Akre, R. D., Greene, A., MacDonald, J. F., Landolt, P. J., \& Davis, H. G. (1980) Yellowjackets of America North of Mexico. U.S. Dept. of Agriculture, Agriculture Handbook No. 552.

Akre, R. D., ReEd, H. C., \& Landolt, P. J. (1982) Nesting biology and behavior of the blackjacket, Vespula consobrina (Hymenoptera: Vespidae). Journal of the Kansas Entomological Society 55,373-405.

Archer, M. E. (1980) Population dynamics. In: Edwards, R. Social Wasps Their Biology and Control. Rentokil Ltd., East Grinstead, Britain (pp 172-207). 
ArCher, M. E. (1981) The Euro-Asian species of the Vespula rufa group (Hymenoptera: Vespidae), with descriptions of two new species and one new subspecies. Kontyu 49,54-64.

Carpenter, J. M. (1982) The phylogenetic relationships and natural classification of the Vespoidea (Hymenoptera). Systematic Entomology 7,11-38.

Cumber, R. A. (1949) The biology of humblebees with special reference to production of the worker caste. Transactions of the Royal Entomological Society of London 100,1-45.

Duncan, C. D. (1939) A contribution to the biology of North American vespine wasps. Stanford University Publications in the Biological Sciences 8,1-272.

Edwards, R. (1980) Social Wasps Their Biology and Control. Rentokil Ltd., East Grinstead, Britain.

Evans, H. E. \& West Eberhard, M. J. (1970) The Wasps. University of Michigan Press, Ann Arbor.

HamiLton, W. D. (1964a) The genetical theory of social behavior. I. Journal of Theoretical Biology 7,1-16.

Hamilton, W. D. (1964b) The genetical theory of social behavior. II. Journal of Theoretical Biology 7,17-52.

Ikan, R., Gottlieb, R., Bergmann, E. D., \& Ishay, J. (1969) The pheromone of the queen of the Oriental hornet, Vespa orientalis. Journal of Insect Physiology $15,1709-12$.

Iwata, K. (1976) Evolution of Instinct Comparative Ethology of Hymenoptera. Amerind, New Delhi.

Jeanne, R. L. (1980) Evolution of social behavior in the Vespidae. Annual Review of Entomology 25,371-96.

Landolt, P. J., Akre, R. D., \& Greene, A. (1977) Effects of colony division on Vespula atropilosa (Sladen) (Hymenoptera: Vespidae). Journal of the Kansas Entomological Society 50,135-47.

LiN, N. \& MiCheneR, C. D. (1972) Evolution of sociality in insects. Quarterly Review of Biology 47,131-59.

MacDonald, J. F., Akre, R. D., \& Hill, W. B. (1974) Comparative biology and behavior of Vespula atropilosa and $V$. pensy/vanica (Hymenoptera: Vespidae). Melanderia 18,1-66.

MacDonald, J. F. \& Matthews, R. W. (1981) Nesting biology of the eastern yellowjacket, Vespula maculifrons (Hymenoptera: Vespidae). Journal of the Kansas Entomological Society 54,433-57.

Montagner, H. (1966) Sur l'origine des males dans les societes de Guepes du genre Vespa. Comptes Rendus des Hebdomadaires des Seances, Paris 263, 785-7.

Perrott, D. C. F. (1975) Factors affecting use of mirex-poisoned protein baits for control of European wasp (Paravespula germanica) in New Zealand. New Zealand Journal of Zoology 2,491-508.

Richards, O. W. (1971) The biology of the social wasps (Hymenoptera: Vespidae). Biological Reviews 46,483-528.

Ross, K. G. (1983) Laboratory studies of the mating biology of the eastern yellowjacket, Vespula maculifrons (Hymenoptera: Vespidae). Journal of the Kansas Entomological Society, In Press. 
Ross, K. G. \& Matthews, R. W. (1982) Two polygynous overwintered Vespula squamosa colonies from the southeastern U.S. (Hymenoptera: Vespidae). Florida Entomologist 65,176-84.

Spradrery, J. P. (1971) Seasonal changes in the population structure of wasp colonies. Journal of Animal Ecology 40,501-23.

Spradbery, J. P. (1973a) Wasps An Account of the Biology and Natural History of Solitary and Social Wasps. University of Washington Press, Seattle.

Spradbery, J. P. (1973b) The European social wasp, Paravespula germanica (F.) (Hymenoptera: Vespidae) in Tasmania, Australia. Proceedings of the VlIth International Congress of the International Union for the Study of Social Insects, London 1973,375-80.

Thомаs, C. R. (1960) The European wasp (Vespula germanica Fab.) in New Zealand. New Zealand Department of Scientific and Industrial Research Information Series 27,1-74.

Tissot, A. N. \& Robinson, F. A. (1954) Some unusual insect nests. Florida Entomologist 37,73-92.

van der Vecht, J. (1957) The vespinae of the Indo-Malayan and Papuan areas (Hymenoptera, Vespidae). Zoologische Verhandelingen 34,1-83.

Vuillaume, M., Schwander, J., \& Roland, C. (1969) Note preliminaire sur l'existence de colonies perennes et polygynes de Paravespula germanica. Comptes Rendus des Hebdomadaires des Seances, Paris 269,2371-2.

West Eberhard, M. J. (1978) Polygyny and the evolution of social behavior in wasps. Journal of the Kansas Entomological Society 51,832-56.

Yamane, SK. (1974) Observations on an orphan nest of Vespa simillima Smith (Hymenoptera, Vespidae). Kontyu 42,404-15. 

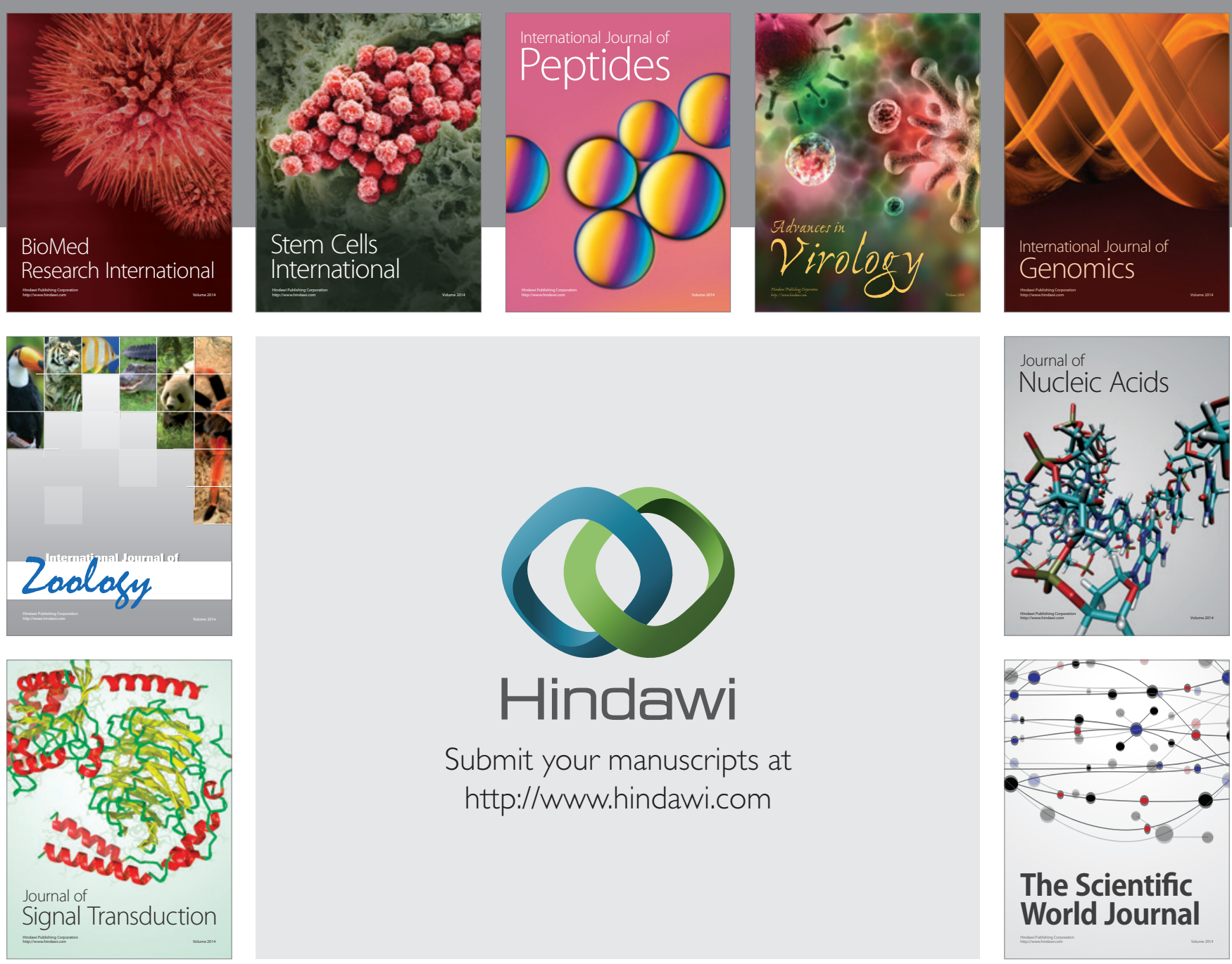

Submit your manuscripts at

http://www.hindawi.com
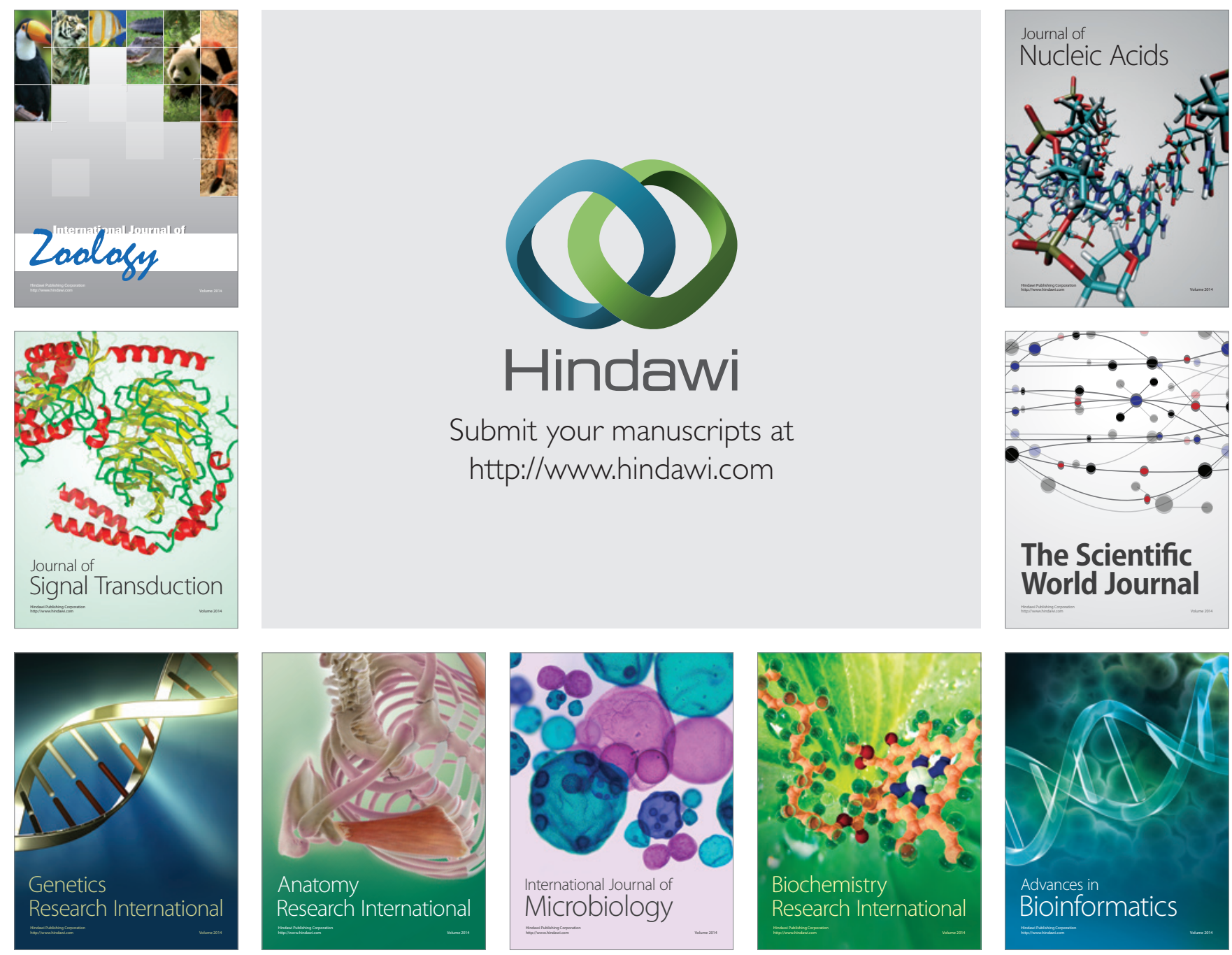

The Scientific World Journal
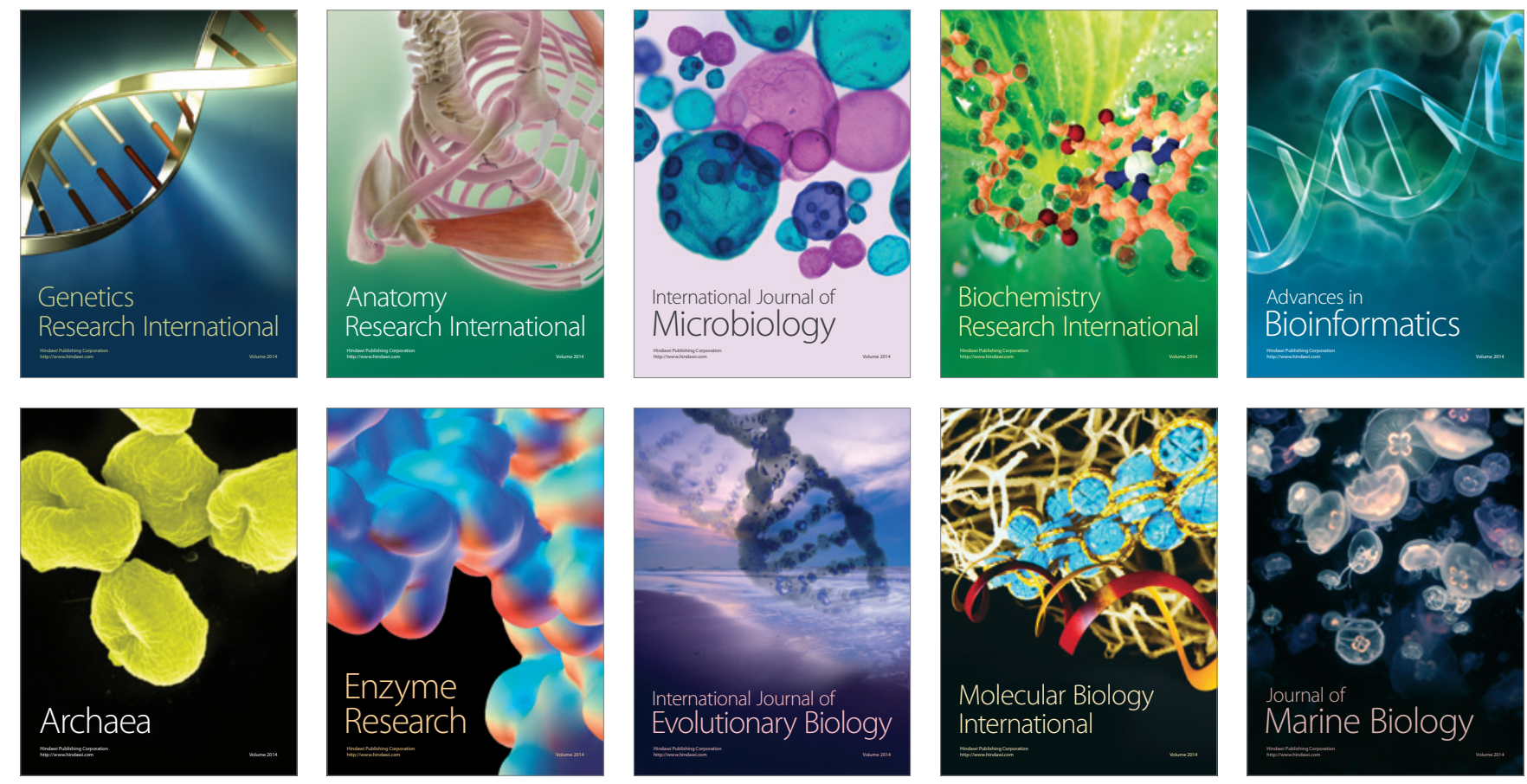